\title{
Distinguished Cd(II) Capture with Rapid and Superior Ability using Porous Hexagonal Boron Nitride: Kinetic and Thermodynamic Aspects
}

\author{
LI Li ${ }^{1}$, GUO Xiaojie ${ }^{2}$, JIN Yang ${ }^{1}$, CHEN Chaogui ${ }^{1}$, Abdullah M Asiri ${ }^{3}$, \\ Hadi M Marwani ${ }^{3}$, ZHAO Qingzhou ${ }^{4}$, SHENG Guodong ${ }^{1}$
}

(1. College of Chemistry and Chemical Engineering, Shaoxing University, Shaoxing 312000, China; 2. College of Materials \& Environmental Engineering, Hangzhou Dianzi University, Hangzhou 310018, China; 3. Chemistry Department, Faculty of Science, King Abdulaziz University, Jeddah 21589, Saudi Arabia; 4. College of Resources and Environment, University of Chinese Academy of Sciences, Beijing 100049, China)

\begin{abstract}
In present work, a systematical and comprehensive understanding for the adsorption of Cd(II) on porous hexagonal boron nitride (p-BN) was studied. The chemical compositions, morphology and surface functional groups of $\mathrm{p}-\mathrm{BN}$ before and after adsorption were characterized by SEM, HRTEM, BET, XRD, and FT-IR. The effects of $\mathrm{pH}$, adsorbent dosage, contact time and temperature on $\mathrm{Cd}(\mathrm{II})$ adsorption were investigated. The maximum adsorption capacity for Cd(II) achieves $184 \mathrm{mg} \cdot \mathrm{g}^{-1}$ at $\mathrm{pH} 7.0$ and $313 \mathrm{~K}$. The kinetic data fitted well with pseudo-second-order model and intra-particle diffusion model, indicating that the adsorption is mainly controlled by chemisorption, and the rate-limiting step is the molecular diffusion. The adsorption isotherms are in accordance with Freundlich and Langmuir model respectively, suggesting Cd(II) adsorbed on the heterogeneous surface through multilayer and monolayer adsorption. The thermodynamic parameters are calculated to confirm the spontaneous and endothermic process of Cd(II) sorption. Spectroscopic results from XPS imply that p-BN adsorbent had substantial functional groups and bonding sites, which is propitious to uptake $\mathrm{Cd}(\mathrm{II})$ from wastewater. These results revealed that $\mathrm{p}-\mathrm{BN}$ is a promising candidate for $\mathrm{Cd}(\mathrm{II})$ scavenging.
\end{abstract}

Key words: boron nitride; adsorption; cadmium; heavy metal ion

With the rapid development of industrialization and urbanization, metals are in high demand and widely used in various fields such as batteries, electroplating, steel industry, etc ${ }^{[1-2]}$. Although metal products have brought countless conveniences to the human, unfortunately, heavy metal ions released into water bodies which have been recognized as serious environmental hazards ${ }^{[2-6]}$. For instance, cadmium is frequently found in effluents industries such as mining, smelting operations, or leather manufacturing. Due to its extreme toxicity, high mobility, high biological accumulation and carcinogenicity ${ }^{[7-10]}$, cadmium ions (Cd(II)) even at a low concentration could pose severe impairment on the human and ecosystem. As a consequence, removal of $\mathrm{Cd}(\mathrm{II})$ from wastewater is of enormous significance to maintain ecological stability and public safety.

Fortunately, various methods, such as chemical co-precipitation, ion exchange, bioremediation, membrane filtration, reverse osmosis, electrochemical treatment and adsorption etc., have been developed to remove Cd(II) from wastewater ${ }^{[11-21]}$.Among these technologies, adsorption has been proved to be feasible, economical and high removal effective which is widely used in wastewater treatment contaminated by heavy metals ${ }^{[2,7,18-21]}$. Thus it is of great importance and difficulty to seek effectual adsorbent with extraordinary efficiency, wide adaptability, environment-friendly and low cost. In this respect, popular materials such as nanosized carbon materials $^{[18,22-24]}$, nanoscale zero valent iron $(\mathrm{NZVI})^{[24-25]}$, carbon nitride ${ }^{[19]}$, layered double hydroxides $(\mathrm{LDHs})^{[26-27]}$ and boron nitride $(\mathrm{BN})$, etc. ${ }^{[28-29]}$ have been employed as adsorbents, and more materials are constantly developed for the removal of $\mathrm{Cd}(\mathrm{II})$ from aqueous solutions.

Hexagonal boron nitride (h-BN) exhibits an isostruc-

Received date: 2019-07-22; Revised date: 2019-09-11

Foundation item: National Natural Science Foundation of China(21777102)

Biography: LI Li(1995-), male, Master candidate. E-mail: 2740033871@qq.com

李 丽(1995-), 女, 硕士研究生. E-mail: 2740033871@qq.com

Corresponding author: CHEN Chaogui, PhD, lecturer. E-mail: cgchen2014@sinano.ac.cn; SHENG Guodong, PhD, associate professor. E-mail: gdsheng@usx.edu.cn 陈朝贵, 博士，讲师. E-mail:cgchen2014@sinano.ac.cn; 盛国栋, 博士，副教授. E-mail:gdshen@usx.edu.cn 
ture of carbon and possesses unique physical and chemical properties, especially numerous strucurual defects, chemical durability and oxidation resistance as compared to carbon materials. These features render porous h-BN (p-BN) outstanding adsorption properties. Consequently, $\mathrm{p}$-BN has been demonstrated to treat a wide range of pollutants, such as dyes, organic solvent, heavy metals and harmful gas, etc ${ }^{[28-29]}$. Notably, adsorption of a series of heavy metals (such as $\mathrm{Pb}, \mathrm{Hg}, \mathrm{Cr}, \mathrm{Ni}, \mathrm{Cu}$ ) have been investigated via $\mathrm{BN}$-based adsorbent ${ }^{[30-35]}$. Li et al. ${ }^{[32]}$ studied $\mathrm{Cr}$ (III) adsorption by fluorinated activated boron nitride. Chen et al. ${ }^{[35]}$ prepared O-doped BN nanosheets as capacitive deionization electrode for efficient removal of heavy metal ions. However, to the best of our knowledge, a comprehensive systematic study for the adsorption of $\mathrm{Cd}$ (II) using p-BN materials is still lacking.

In present work, the adsorption of $\mathrm{Cd}$ (II) on $\mathrm{p}$-BN was systematically evaluated. The $\mathrm{p}-\mathrm{BN}$ compounds before and after adsorption were specifically characterized. The adsorption performance was evaluated by batch experiments, in which the effects of initial $\mathrm{pH}$, adsorbent dosage, contact time and temperature were investigated in details. The adsorption kinetics and thermodynamic were also discussed to understand the mechanism of adsorption.

\section{Materials and methods}

\subsection{Materials}

The p-BN microrods were synthesized by a modified two-step-synthesis method ${ }^{[36]}$. In brief, analytical grade melamine and boric acid (mole ratio=1:2) purchased from Aladdin were used directly without further purification to prepare precursor and the final product was obtained by subsequent high temperature calcination (1373 K for $1 \mathrm{~h}$ ). Experimental solutions were prepared by using $18 \mathrm{M} \Omega \cdot \mathrm{cm}$ de-ionized water (Millipore Milli-Q water purification system) under ambient conditions. The other chemicals used in this study were of analytical grade.

\subsection{Characterization}

The morphology and the element contents were analyzed by scanning electron microscope (SEM, JSM-6360LV) and high resolution transmission electron microscope (HRTEM, JEM-2100F), respectively. The surface area, volume of micropore were determined by the BrunauerEmmett-Teller method (BET, Empyrean, Micromeritics) at $77 \mathrm{~K}$. Before measurement, the samples were activated in vacuum at $573 \mathrm{~K}$ for $8 \mathrm{~h}$. The crystal structure was recorded by X-ray diffraction (XRD, Empyrean) with $\mathrm{Cu}$ $\mathrm{K} \alpha$ radiation. The changes of functional groups of compounds before and after adsorption were identified by a Fourier transform infrared spectrometer (FT-IR, NEXUS) with a scan range of $400-4000 \mathrm{~cm}^{-1}$. The X-ray photo- electron spectrum (XPS) was conducted by a Thermo ESCALAB250 with a focused monochromatized Al Ka X-ray source $(\mathrm{hm}=1486.6 \mathrm{eV})$. The concentration of $\mathrm{Cd}(\mathrm{II})$ was measured by flame atomic absorption spectroscope (AAS, AA-7000).

\subsection{Batch experiment}

$\mathrm{Cd}\left(\mathrm{NO}_{3}\right)_{2} \cdot 4 \mathrm{H}_{2} \mathrm{O}$ as the sources of $\mathrm{Cd}(\mathrm{II})$ was used to prepare aqueous stock $\mathrm{Cd}(\mathrm{II})$ solution. $\mathrm{Cd}(\mathrm{II})$ solutions with different initial concentrations were prepared by diluting $\mathrm{Cd}(\mathrm{II})$ stock solutions with fixed ratio. Small volumes of $0.10 \mathrm{~mol} \cdot \mathrm{L}^{-1} \mathrm{HCl}$ and/or $\mathrm{NaOH}$ solutions were used to adjust the initial $\mathrm{pH}$ of test solutions. $\mathrm{pH}$ was set at 7.0 after optimization. The Batch adsorption experiment was conducted by adding a certain amount of p-BN adsorbent to $50.0 \mathrm{~mL} \mathrm{Cd(II)} \mathrm{solutions} \mathrm{with} \mathrm{differ-}$ ent initial concentrations, and then shaken at $313.0 \mathrm{~K}$ for $24 \mathrm{~h}$ to ensure adsorption equilibrium. For the adsorption kinetic study, p-BN adsorbent was set at $10.0 \mathrm{mg}$ and $\mathrm{Cd}(\mathrm{II})$ solutions with different initial concentrations (40, $60,80 \mathrm{mg} \cdot \mathrm{L}^{-1}$ ) were employed. To obtain sorption isotherms of $\mathrm{Cd}(\mathrm{II})$ on $\mathrm{p}-\mathrm{BN}$, the operation temperature was set at 303, 313 and $333 \mathrm{~K}$. Finally, the solid was separated from aqueous solution via filtration through $0.22-\mu \mathrm{m}$ polyethersulfone membrane filters. And then $0.5 \mathrm{~mL}$ supernatant and $0.5 \mathrm{~mL} \mathrm{HNO}_{3}(\mathrm{pH}=2)$ were diluted to $25.0 \mathrm{~mL}$ for determination.

The adsorption of $\mathrm{p}-\mathrm{BN}$ is represented by removal (Ads\%) and the adsorption capacity $(q)$ which is the amount of $\mathrm{Cd}(\mathrm{II})$ adsorbed on the sorbent per unit weight. The adsorption capacity at equilibrium and any time $t$ are indicated by $q_{\mathrm{e}}$ and $q_{t}\left(\mathrm{mg} \cdot \mathrm{g}^{-1}\right)$. The relevant parameters are calculated by the formula (1-3):

$$
\begin{gathered}
\text { Ads } \%=\frac{C_{0}-C_{\mathrm{e}}}{C_{0}} \times 100 \% \\
q_{t}=\frac{\left(C_{0}-C_{t}\right) \times V}{m} \\
q_{\mathrm{e}}=\frac{\left(C_{0}-C_{\mathrm{e}}\right) \times V}{m}
\end{gathered}
$$

where $C_{0}\left(\mathrm{mg} \cdot \mathrm{L}^{-1}\right)$ is the initial $\mathrm{Cd}(\mathrm{II})$ concentration, $C_{t}$ and $C_{\mathrm{e}}$ are the concentration at time $t$ and equilibrium, $m(\mathrm{~g})$ is the amount of adsorbent and $V(\mathrm{~L})$ is the volume of solution. All batch experiments were performed in duplicates or triplicates in order to ensure the data accuracy and repeatability. The average of the acquired data was used for subsequent analysis.

\section{Results and discussion}

\subsection{Morphology and structure}

The morphologies and structures of $\mathrm{p}-\mathrm{BN}$ materials 
before and after adsorption were characterized by SEM, HRTEM, as shown in Fig.1. As depicted in SEM image (Fig. 1(A)), the bare p-BN is composed of a large number of irregular micro rods, with a length ranging from a few micrometers to tens of micrometers. Meanwhile, the corresponding HRTEM image (Fig. 1(B)) shows that $\mathrm{p}$-BN has a homogenous porous structure, for which numerous visible nanopores (Fig. 1(B) dotted circle) are evenly distributed on the micro rods. In comparison, no significant changes are found in low-magnification images of p-BN after adsorption, as shown in Fig. 1(C). Because of the ultrasonic treatment, $\mathrm{p}$-BN micro rods appear to be more fragmented. However, a large number of unidentified black dots appear on the surface of the adsorbed p-BN micro rods in HRTEM image (Fig. 1(D)). The high-resolution HRTEM image (Fig. 1(F)) indicates that the dots are nano-sized particles (Fig. 1(F) dotted circle) containing high-component Cd element (Fig. S1). The EDS pattern (Fig. 1(E)) shows that the adsorbed boron nitride showed a distinct peak of $\mathrm{Cd}$, which means that $\mathrm{Cd}(\mathrm{II})$ has adsorbed onto p-BN material.

\subsection{Crystal structure and surface functional groups}

Fig. 2(A) presents the XRD patterns of $\mathrm{p}-\mathrm{BN}$ before and after adsorption. It can be seen that there exists two broad peaks at $2 \theta=\sim 25.5^{\circ}$ and $\sim 42.5^{\circ}$, which could be assigned to (002) and (100) fringes of h-BN with poor crystallization $^{[34]}$. It is noteworthy that the calculated interplanar distances of (002) plane is $0.35 \mathrm{~nm}$ which is a little larger than that of raw h-BN. The enlarged interspace can be attributed to a similar turbostratic $\mathrm{BN}$ structure observed in previous report ${ }^{[30]}$. Furthermore, after adsorption, it is found that the high-intensity peak (002) shifted to the right of $+0.8^{\circ}$, which could relate to the emergence of new substances and/or lattice deformation. The appearance of low-intensity peaks at $\sim 23.6^{\circ}$, $\sim 30.3^{\circ}, \sim 36.4^{\circ}, \sim 49.9^{\circ}$ come from a new substance, which is considered to be a highly similar compound
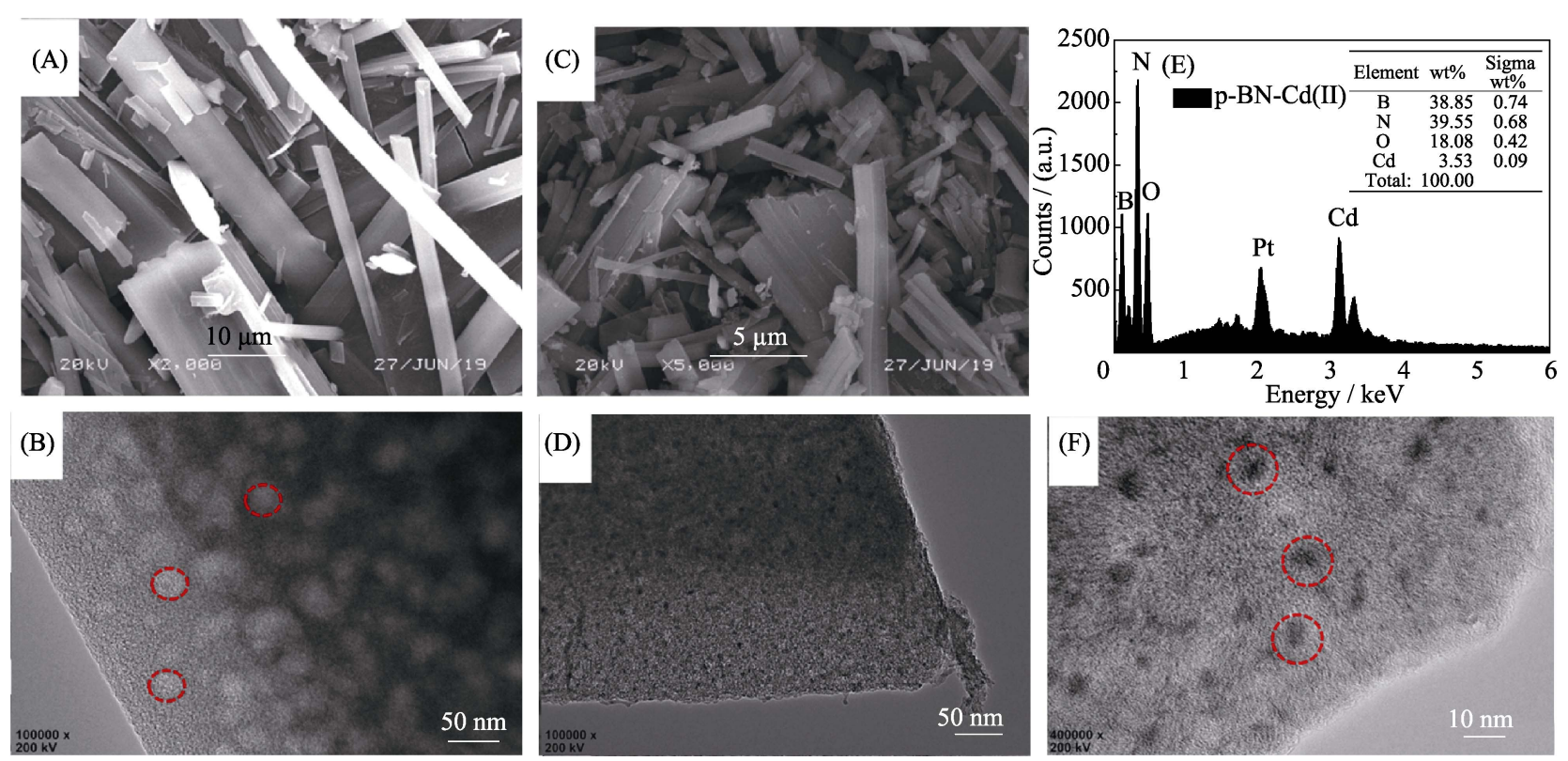

Fig. 1 (A) SEM and (B) HRTEM images of p-BN, (C) SEM and (D) HRTEM images of p-BN after adsorption,

(E) EDS analysis and (F) high-magnification HRTEM image of p-BN after adsorption
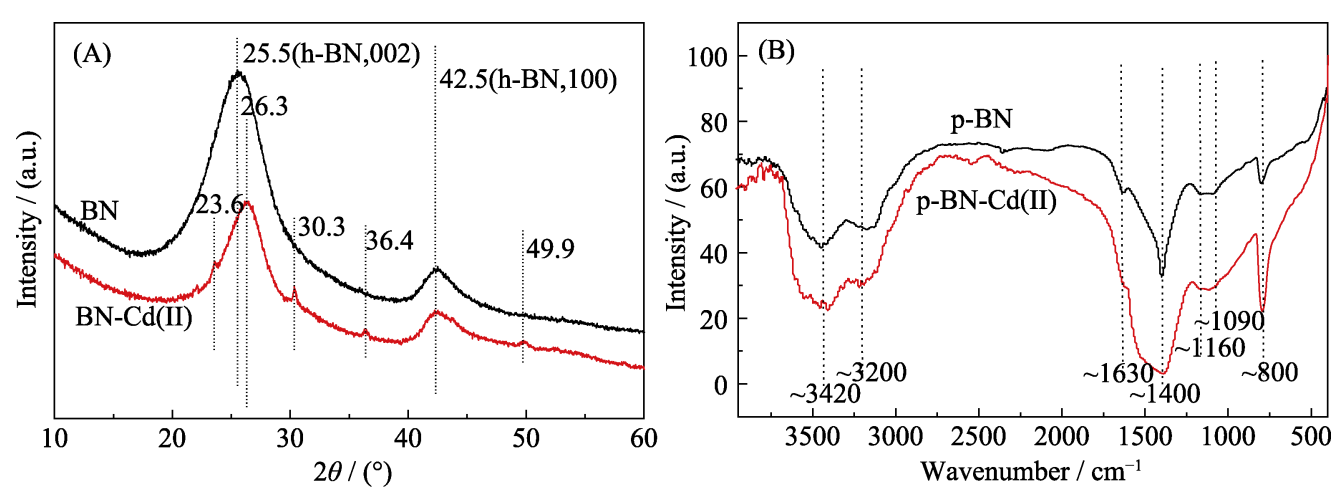

Fig. 2 XRD patterns (A) and FT-IR spectra (B) of p-BN before and after adsorption 
of otavite, syn $\left(\mathrm{CdCO}_{3}\right.$, JCPDS 42-1342). The observed peaks are consistent with the corresponding lattice planes of $\quad(012)\left(23.49^{\circ}\right), \quad(104)\left(30.28^{\circ}\right), \quad(110)\left(36.42^{\circ}\right) \quad$ and $(116)\left(49.9^{\circ}\right)$. These contribute to analyze the possible adsorption mechanisms.

The surface functional groups of $\mathrm{p}-\mathrm{BN}$ before and after adsorption were estimated by FT-IR (Fig. 2(B)). Typically, corresponding to the $\mathrm{sp}_{2}$-bonded $\mathrm{B}-\mathrm{N}$ and $\mathrm{B}-\mathrm{N}-\mathrm{B}$ bending vibration, two strong characteristic absorption bands were observed at $\sim 1400$ and $\sim 800 \mathrm{~cm}^{-1}$, respectively, indicating the main crystalline structures of hexagonal BN existed ${ }^{[37]}$. The characteristic adsorption peaks at $\sim 3420$ and $\sim 1160 \mathrm{~cm}^{-1}$ were consistent with $\mathrm{B}-\mathrm{OH}$ and $\mathrm{B}-\mathrm{N}-\mathrm{O}$ stretching and peaks close-by $\sim 3200 \mathrm{~cm}^{-1}$ attributed to $\mathrm{B}-\mathrm{NH}_{2}$ stretching vibrations ${ }^{[38]}$. The presences of $\mathrm{B}-\mathrm{OH} / \mathrm{B}-\mathrm{NH}_{2}$ groups provide abundant basic sites which facilitates electrostatic adsorption of positively-charged ions under alkaline conditions. The adsorption peaks at $\sim 1630$ and $\sim 1090 \mathrm{~cm}^{-1}$ can be attributed to $\mathrm{C}=\mathrm{O}$ and $\mathrm{C}-\mathrm{O}$ stretching vibrations, which may be related to the addition of triblock copolymers as structure directing agents ${ }^{[36]}$. It is noteworthy that after adsorption, the broad band intensities ranges from 3000 to $3600 \mathrm{~cm}^{-1}$ and 1200 to $1600 \mathrm{~cm}^{-1}$ increase and are consistent with amine and imine hydrohalide $\mathrm{N}-\mathrm{H}^{+} / \mathrm{N}-\mathrm{H}_{2}{ }^{+}$stretching vibrations ${ }^{[39]}$. We also conducted BET characterization of the material, and the results are shown in Fig. S2.

\subsection{Influence of $\mathrm{pH}$ and sorbent dosage}

The role of acidity in $\mathrm{Cd}(\mathrm{II})$ adsorption on $\mathrm{p}-\mathrm{BN}$ was studied with $\mathrm{pH}$ ranging from 1.0 to 7.0 and presented in Fig. 3(A). It can be revealed that the initial $\mathrm{pH}$ has a significant effect on the $\mathrm{Cd}(\mathrm{II})$ adsorption. Low $\mathrm{pH}$ is not favor of the adsorption, since in that range cadmium ions are present in free form as $\mathrm{Cd}^{2+}$ ions (Fig. S3), while more proton are available on the surface of $\mathrm{p}-\mathrm{BN}$ to produce protonate amino/hydroxyl groups. Hence, the electrostatic repulsion force between $\mathrm{p}$-BN surface and the cation of $\mathrm{Cd}^{2+}$ inhibits the adsorption. With the increase of $\mathrm{pH}$, the deprotonation of the surface functional groups result in more adsorption activity sites for $\mathrm{Cd}(\mathrm{II})$, and the adsorption gradually increases. Additionally, the distribution of the morphological species of $\mathrm{Cd}(\mathrm{II})$ is affected by the concentration of $\mathrm{Cd}(\mathrm{II})$ and $\mathrm{pH}$. An excessive alkaline environment may result in strong hydrolyzed precipitation of cadmium ions which causes large deviations from experimental results (Fig. S3). Based on all the considerations, $\mathrm{pH}$ of the solution is set at 7.0, which is close to the $\mathrm{pH}$ of the surface water, for our subsequent experiments. In previous reports, Liao et al. ${ }^{[19]}$ studied $\mathrm{pH}$ effect on $\mathrm{Cd}(\mathrm{II})$ sorption onto $\mathrm{g}-\mathrm{C}_{3} \mathrm{~N}_{4}$ nanosheets. Paola et al ${ }^{[22]}$ studied $\mathrm{pH}$ effect on $\mathrm{Cd}(\mathrm{II})$ sorption onto modified $\mathrm{N}$-doped carbon nanotubes.
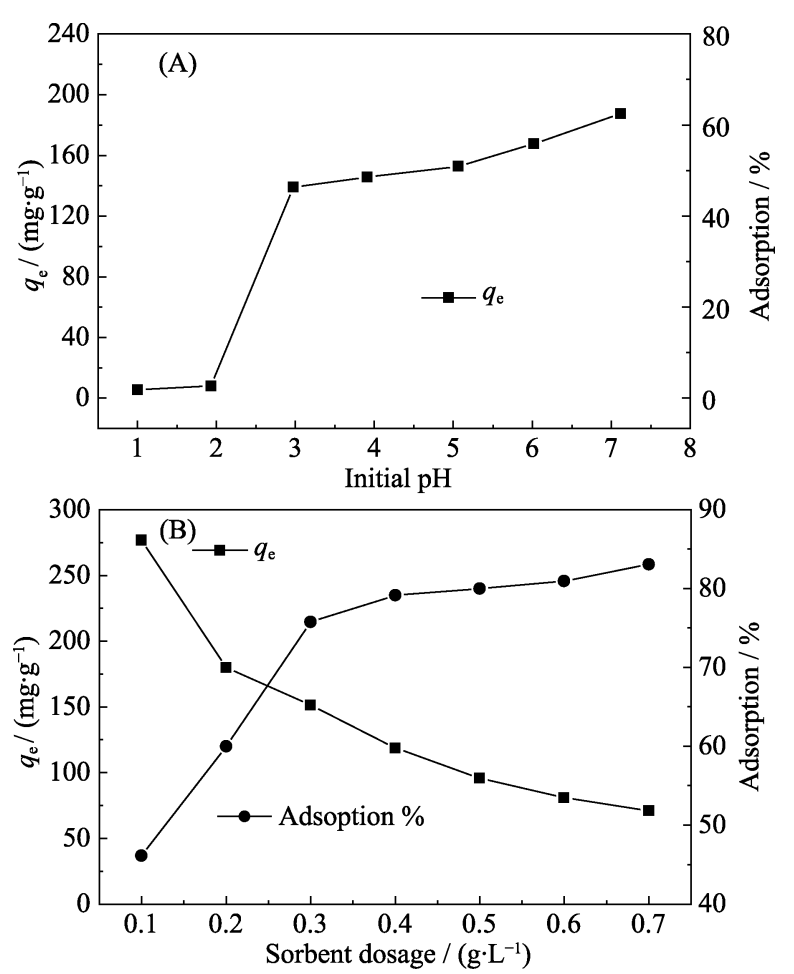

Fig. 3 (A) Effect of initial $\mathrm{pH}$ on $\mathrm{Cd}(\mathrm{II})$ adsorption capacity $\left(q_{\mathrm{e}}\right)$ and adsorption percentage at equilibrium, and (B) effect of p-BN dosage on the adsorption capacity $\left(q_{\mathrm{e}}\right)$ and adsorption percentage of $\mathrm{Cd}(\mathrm{II})$

Huang et al. ${ }^{[23]}$ studied the effect of $\mathrm{pH}$ on $\mathrm{Cd}(\mathrm{II})$ sorption onto graphene oxides. And similar results were found. Fig. 3(B) presents the influence of adsorbent dosage on the adsorption. These results give a chance to expect less sorbent consumption or higher efficiencies of adsorption. It can be clearly seen that the adsorption percentage of $\mathrm{Cd}(\mathrm{II})$ rises with the increase of $\mathrm{p}$-BN dosage and tends to be stable near $\sim 80 \%$ after the adsorbent concentration reaches $0.4 \mathrm{~g} \cdot \mathrm{L}^{-1}$. In contrast, the adsorption gradually decreases with the dose of $\mathrm{p}-\mathrm{BN}$ increasing. The reasons for this phenomenon can be ascribed to the fact that: firstly, the surface active sites of $\mathrm{p}$-BN increase with the concentration of $\mathrm{p}-\mathrm{BN}$; secondly, when the concentration of adsorbed ions in solution is low to a certain extent, the dynamic equilibrium of adsorption/desorption inhibits the increasing adsorption. It can be deduced to a chemisorption process for $\mathrm{Cd}(\mathrm{II})$ adsorption.

\subsection{Adsorption kinetics}

Fig. 4 presents the uptake of $\mathrm{Cd}(\mathrm{II})$ on $\mathrm{p}-\mathrm{BN}$ as a function of contact time at various initial concentrations of $\mathrm{Cd}(\mathrm{II})$. Obviously, as the concentration of $\mathrm{Cd}(\mathrm{II})$ increases, the adsorption capacity increases (Fig. 4(A)) while removal percentage decreases (Fig. 4(B)). It is noteworthy that at a constant dosage of $\mathrm{p}$-BN adsorbent, the adsorption capacity increases rapidly with $\mathrm{Cd}(\mathrm{II})$ concentration increasing, indicating that the adsorption behavior does not depend on amounts of surface active groups. On the 
other hand, the adsorptive quantity of $\mathrm{Cd}(\mathrm{II})$ increases quickly during the first $3 \mathrm{~h}$, and then gradually increases until equilibrium. The adsorption capacity can reach $219.7 \mathrm{mg} \cdot \mathrm{g}^{-1}$ at $C_{\mathrm{cd}}=80 \mathrm{mg} \cdot \mathrm{L}^{-1}$. Furthermore, the variation of adsorption capacity with contact time can be utilized for constructing adsorption kinetic models, reflecting the relationship between the structure of adsorbent and adsorption performance. The adsorption and consequence can also be predicted or verified. Particularly, subsequent kinetic analysis is achieved from experimental data $q_{\mathrm{e}}-t$ curve for $C_{\mathrm{cd}}=60 \mathrm{mg} \cdot \mathrm{L}^{-1}$. In the present work, the adsorption kinetics was simulated by 4 kinetic models to investigate the possible mechanism for removal process, which named as pseudo-first-order model, pseudo-second-order model, intra-particle diffusion model and liquid-film diffusion. The linearized forms of the 4 models are expressed by the equations (4-7):

Pseudo-first-order model:

$$
\ln \left(q_{\mathrm{e}}-q_{t}\right)=\ln q_{\mathrm{e}}-k_{1} t
$$

Pseudo-second-order model:

$$
\frac{t}{q_{t}}=\frac{1}{k_{2} q_{\mathrm{e}}^{2}}+\frac{t}{q_{\mathrm{e}}}
$$

Intra-particle diffusion model:

$$
q_{t}=k_{\mathrm{d}} t^{1 / 2}+I
$$

Liquid-film diffusion model:

$$
\ln \left(1-\frac{q_{t}}{q_{\mathrm{e}}}\right)=-k_{\mathrm{f}} t+A
$$

where $k_{1}\left(\mathrm{~h}^{-1}\right)$ and $k_{2}\left(\mathrm{~g} \cdot \mathrm{mg}^{-1} \cdot \mathrm{h}^{-1}\right)$ are the rate constants of the first and the second order adsorption for $\mathrm{Cd}(\mathrm{II})$. $k_{\mathrm{d}}\left(\mathrm{g} \cdot \mathrm{mg}^{-1} \cdot \mathrm{h}^{-1 / 2}\right)$ is the rate constant of intra-particle diffusion and $k_{\mathrm{f}}$ is the rate constant of liquid-film diffusion. $I$ is a parameter relate to the thickness of the boundary layer, $A$ is liquid-film diffusion constant ${ }^{[40-41]}$. The detailed results of the fitting results by 4 kinetic models are shown in Fig. S4 and Table S1.

\subsection{Adsorption isotherm and thermodynamics}

Adsorption isotherms of $\mathrm{Cd}(\mathrm{II})$ on $\mathrm{p}-\mathrm{BN}$ at $T=303$, 313 and $323 \mathrm{~K}$ are depicted in Fig. 5(A), describing the relation between $C_{\mathrm{e}}$ and $q_{\mathrm{e}}$. Not surprisingly, adsorption capacity of adsorbent increases with the increase of temperature, which confirm that high temperature is propitious to adsorption behavior. Most importantly, the variation of the adsorption isotherm contributes to analyze the interaction between adsorbent and adsorbate, and the structural characteristics of the adsorbed layer. Therefore, Langmuir, Freundlich and Tempkin models are adopted for fitting experimental data and the linearized forms of the three models are expressed by the equations (8-10):
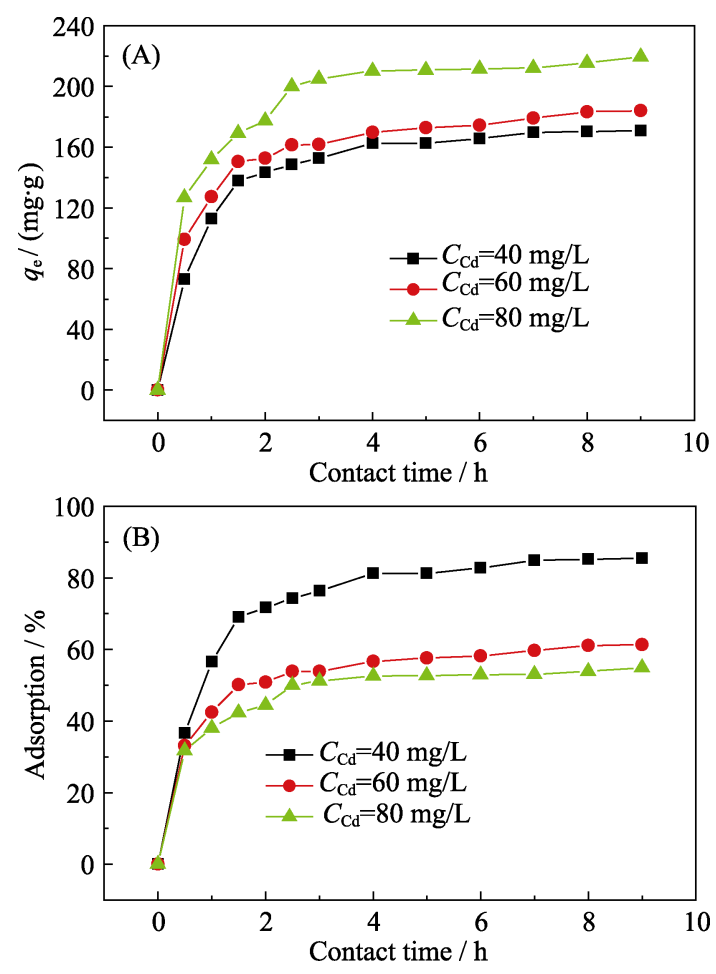

Fig. 4 (A) Adsorption capacities of $\mathrm{Cd}$ (II) with various contact time at different initial concentrations of $\mathrm{Cd}(\mathrm{II})$, and (B) adsorption percentages of $\mathrm{Cd}(\mathrm{II})$ on $\mathrm{p}$-BN with various contact time at different initial concentrations of $\mathrm{Cd}(\mathrm{II})$

Langmuir model:

$$
\frac{1}{q_{\mathrm{e}}}=\frac{1}{q_{\mathrm{m}}}+\frac{1}{K_{\mathrm{L}} q_{\mathrm{m}}} \times \frac{1}{C_{\mathrm{e}}}
$$

Freundlich model:

$$
\ln q_{\mathrm{e}}=\ln K_{\mathrm{F}}+\frac{1}{n} \ln C_{\mathrm{e}}
$$

Tempkin model:

$$
q_{\mathrm{e}}=K_{\mathrm{T}} \ln f+K_{\mathrm{T}} \ln C_{\mathrm{e}}
$$

where $K_{\mathrm{L}}\left(\mathrm{L} \cdot \mathrm{mg}^{-1}\right)$ is the Langmuir adsorption constant about the affinity of binding sites; $K_{\mathrm{F}}$ is the Freundlich constant which reflects the adsorption ability and $n$ is non-linear factor relate to heterogeneous energy of adsorption surface. $K_{\mathrm{T}}\left(\mathrm{L} \cdot \mathrm{mg}^{-1}\right)$ is the constant associated with the adsorption heat and $f$ is the Tempkin equilibrium constant corresponding to maximum binding energy. Fig. 5(B-D) show the fitting results by isotherm models and the corresponding parameters and correlation coefficients are listed in Table 1. In contrast to Langmuir model (Fig. 5(B)), Freundilich model (Fig. 5(C)) fits the isotherm better with high correlation coefficient, indicating that $\mathrm{Cd}(\mathrm{II})$ are adsorbed on a heterogeneous surface through multilayer and monolayer adsorption ${ }^{[19,42]}$. Based on analysis of Freundilich model, the smaller the numerical value of $1 / n$ is, the better adsorption will be. It is clear that $1 / n(0.22-0.23)$ is small, which illustrates a favor- 
able adsorption process. Applying to the adsorption system with heterogeneous surface, the linear fit of Tempkin model (Fig. 5(D)) has a high correlation coefficient $(\sim 0.99)$, demonstrating that the decrease in adsorption heat with adsorption capacity is linear energy dependence rather than exponential one. This is possibly ascribed to a certain strong chemical bonding interactions between $\mathrm{Cd}$ (II) and p-BN adsorbent. The thermodynamic parameters of the adsorption, i.e. the values of standard Gibbs free energy $\left(\Delta G^{\theta}\right)$, enthalpy $\left(\Delta H^{\theta}\right)$ and entropy $\left(\Delta S^{\theta}\right)$ are shown in Fig. S5 and Table S2.

\subsection{XPS analysis}

In order to identify the bonding states and their compositions of $\mathrm{p}$-BN before and after absorption, XPS spectra were also investigated and presented in Fig. 6. It can be clearly seen that the main constituent elements (B, $\mathrm{N}, \mathrm{O}$ ) are detected in XPS spectra of total surveys for p-BN (Fig. 6(A)). Meanwhile, the presence of double peaks at around $\sim 410 \mathrm{eV}$ is due to the orbital spin splitting of the $3 \mathrm{~d}$ layer electrons of $\mathrm{Cd}(\mathrm{II})$, corresponding to $\mathrm{Cd} 3 \mathrm{~d}_{5 / 2}$ and $\mathrm{Cd} 3 \mathrm{~d}_{3 / 2}$ in the inset of Fig. 6(A), respectively ${ }^{[43]}$. These results confirm the successful adsorption of $\mathrm{Cd}(\mathrm{II})$ on $\mathrm{p}-\mathrm{BN}$ in consistent with the EDS results in Fig. 1(E). High resolution Cd3d XPS spectrum is depicted in Fig. 6(B), a double peak is observed at 405.7 and $412.4 \mathrm{eV}$, which is assigned to $\mathrm{Cd} 3 \mathrm{~d}_{5 / 2}$ and $\mathrm{Cd} 3 \mathrm{~d}_{3 / 2}$ as mentioned before. Compared with the primary peaks of $\mathrm{Cd} 3 \mathrm{~d}_{5 / 2}(405.0 \mathrm{eV})$ and $\mathrm{Cd} 3 \mathrm{~d}_{3 / 2}(411.7 \mathrm{eV})$ for free
$\mathrm{Cd}(\mathrm{II})$ ions, the existence of a shift of $+0.7 \mathrm{eV}$ toward higher bonding energy can be attributed to the interaction between $\mathrm{Cd}(\mathrm{II})$ and the adsorbent ${ }^{[43]}$. Similarly, the peaks of N1s and O1s obtained a little left shift after the adsorption, which suggest a possible interaction between $\mathrm{B}$ (or N) atom and $\mathrm{Cd}(\mathrm{II})$ (Fig. S6). Besides, recognized as two common cadmium precipitates in aqueous solution, the photoelectron binding energies of $\mathrm{Cd}(\mathrm{II})$ in $\mathrm{CdCO}_{3}$ $(405.4 \mathrm{eV})$ and $\mathrm{Cd}(\mathrm{OH})_{2}(406.7 \mathrm{eV})$ are also illustrated in Fig. 6(B) for comparison. The experimental peaks located at 405.7 and $412.4 \mathrm{eV}$ can be fitted into several peaks, and the split peaks can be attributed to the complexation of $\mathrm{Cd}(\mathrm{II})$ and numerous strucurual defects among p-BN adsorbent, exampling as polar bonds of $\mathrm{B}-\mathrm{O}$, $\mathrm{B}-\mathrm{N}$ and $\mathrm{C}-\mathrm{O}$, etc ${ }^{[44]}$. These results imply that $\mathrm{p}-\mathrm{BN}$ adsorbent has substantial functional groups and bonding sites, which is propitious to uptake $\mathrm{Cd}(\mathrm{II})$ from wastewater.

\section{Conclusions}

In summary, the adsorption performances and mechanism of $\mathrm{p}-\mathrm{BN}$ for $\mathrm{Cd}$ (II) were systematically studied. The results demonstrate that $\mathrm{p}-\mathrm{BN}$ is an effective adsorbent for $\mathrm{Cd}(\mathrm{II})$ in aqueous solution, and its adsorption capacity highly depends on contact time, $\mathrm{pH}$ and temperature. In a neutral water environment $(\mathrm{pH}=7.0)$, the maximum adsorption capacity can reach $184 \mathrm{mg} \cdot \mathrm{g}^{-1}$ at $313 \mathrm{~K}$. The pseudo-second-order equation fits well with the adsorption process, indicating that the adsorption process is
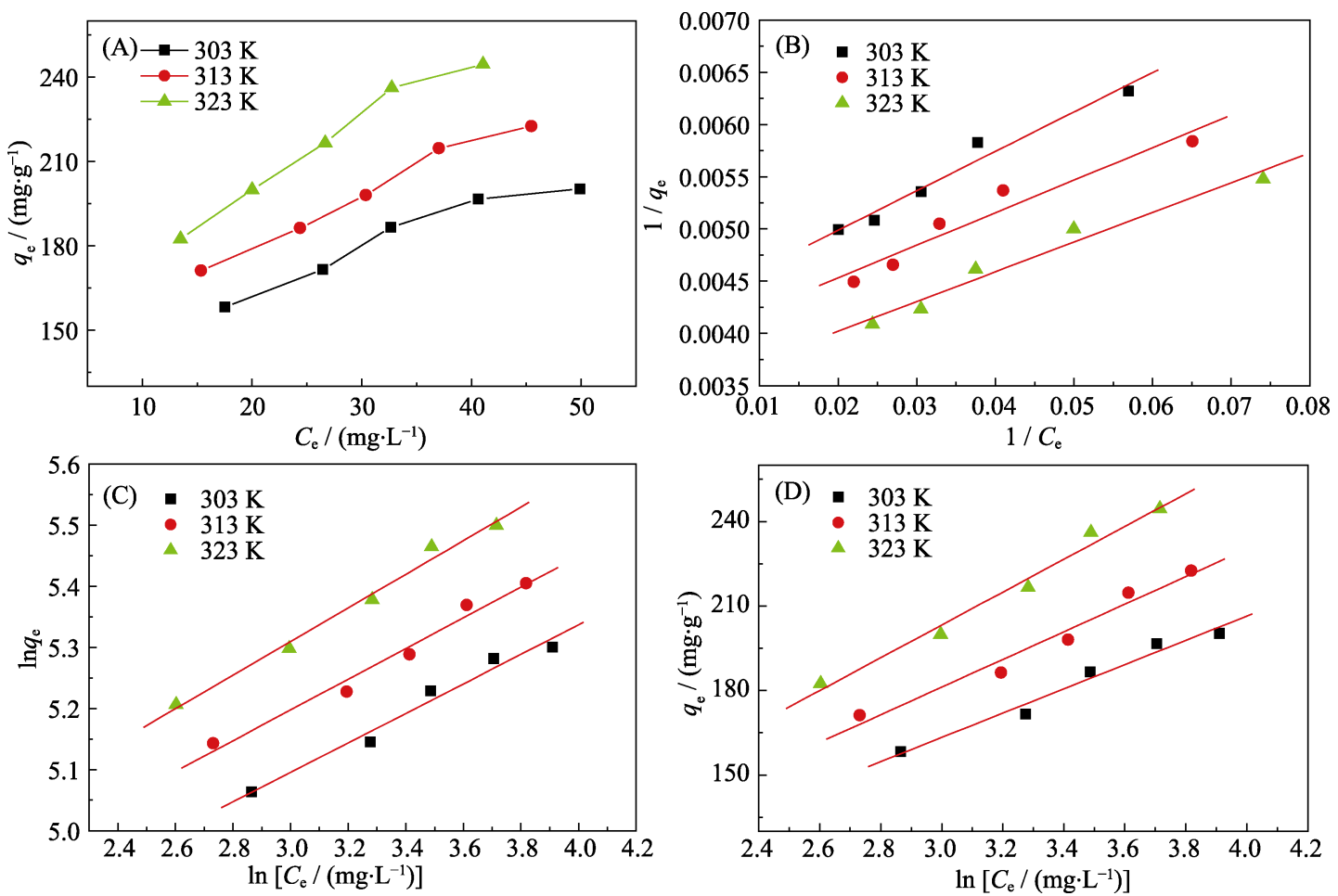

Fig. 5 (A) Adsorption isotherms of $\mathrm{Cd}(\mathrm{II})$ on $\mathrm{p}-\mathrm{BN}$ at $T=303,313$ and $323 \mathrm{~K}$, equilibrium adsorption isotherms fitted by (B) Langmuir model, (C) Freundlich model, (D) Tempkin model Experimental conditions: Initial $\mathrm{pH}$ at $7.0, C_{0}=60 \mathrm{mg} \cdot \mathrm{L}^{-1}, m=10.0 \mathrm{mg}, V=50 \mathrm{~mL}$ 
Table 1 Adsorption isotherm models parameters of $\mathrm{Cd}(\mathrm{II})$ on p-BN

\begin{tabular}{|c|c|c|c|c|c|c|c|c|c|c|}
\hline \multirow{2}{*}{\multicolumn{2}{|c|}{$\begin{array}{c}\text { Model } \\
\text { parameter }\end{array}$}} & \multicolumn{3}{|c|}{ Langmuir model } & \multicolumn{3}{|c|}{ Freundlich model } & \multicolumn{3}{|c|}{ Tempkin model } \\
\hline & & $q_{\mathrm{m}} /\left(\mathrm{mg} \cdot \mathrm{g}^{-1}\right)$ & $K_{\mathrm{L}} /\left(\mathrm{L} \cdot \mathrm{mg}^{-1}\right)$ & $R^{2}$ & $1 / n$ & $K_{\mathrm{F}}$ & $R^{2}$ & $K_{\mathrm{T}} /\left(\mathrm{L} \cdot \mathrm{mg}^{-1}\right)$ & $f$ & $R^{2}$ \\
\hline \multirow{3}{*}{$T / \mathrm{K}$} & 303 & 236 & 0.112 & 0.984 & 0.229 & 1.27 & 0.987 & 43.1 & 2.19 & 0.987 \\
\hline & 313 & 256 & 0.126 & 0.968 & 0.225 & 1.29 & 0.989 & 49.1 & 2.00 & 0.984 \\
\hline & 323 & 290 & 0.121 & 0.983 & 0.223 & 1.32 & 0.994 & 58.3 & 1.63 & 0.991 \\
\hline
\end{tabular}
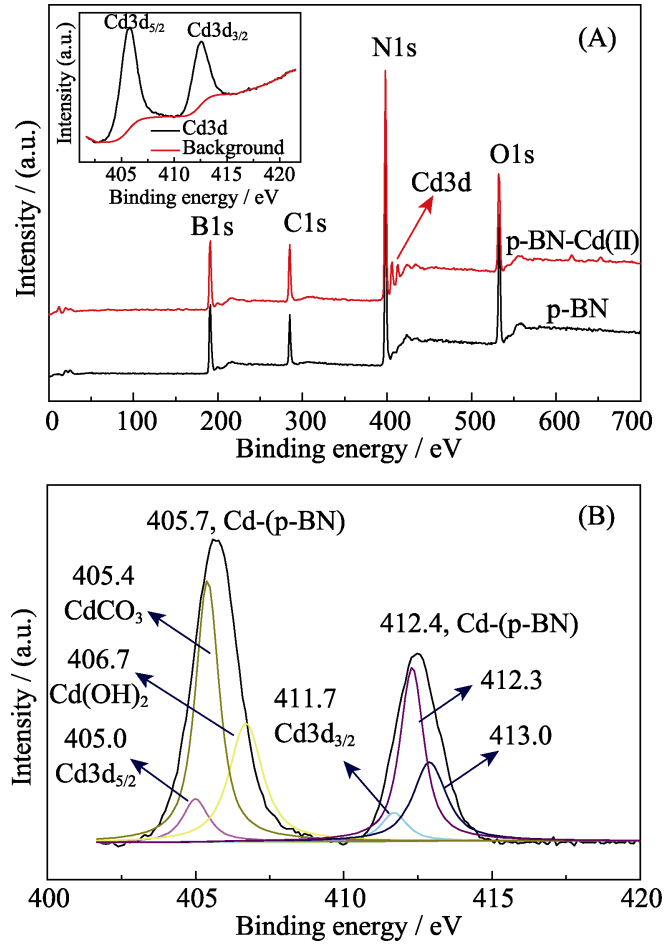

Fig. 6 (A) XPS surveys for p-BN and adsorbed p-BN(inset: high resolution Cd3d XPS spectrum and background); (B) Experimental bonding enerygy peaks of $\mathrm{Cd}(\mathrm{II})$ and the comparisons of primary peaks of $\mathrm{Cd} 3 \mathrm{~d}_{5 / 2}$ and $\mathrm{Cd} 3 \mathrm{~d}_{3 / 2}$ for free $\mathrm{Cd}(\mathrm{II})$, $\mathrm{CdCO}_{3}, \mathrm{Cd}(\mathrm{OH})_{2}$

mainly controlled by chemisorption. The intra-particle diffusion model demonstrates that the rate limiting step is primarily molecular diffusion of $\mathrm{Cd}$ (II) in the micropores of $\mathrm{p}$-BN. Isotherm studies present that $\mathrm{Cd}(\mathrm{II})$ sorption on p-BN complies well with Freundlich and Langmuir model, respectively, implying $\mathrm{Cd}(\mathrm{II})$ were adsorbed on the heterogeneous surface through multilayer and monolayer adsorption. The thermodynamic parameters confirm that the adsorption of $\mathrm{Cd}(\mathrm{II})$ on $\mathrm{p}-\mathrm{BN}$ is a spontaneous endothermic process and high temperature is beneficial to the adsorption. Considering the above results, $\mathrm{p}$-BN is a very promising candidate for $\mathrm{Cd}(\mathrm{II})$ removal from aqueous solution.

\section{Supporting materials}

Supporting materials related to this article can be found at https://doi.org/10.15541/jim20190371.

\section{References:}

[1] ZOU YI-DONG, WANG XIANG-XUE, KHAN A, et al. Environmental remediation and application of nanoscale zero-valent iron and its composites for the removal of heavy metal ions: a review. Environmental Science \& Technology, 2016, 50(14): 7290-7304.

[2] LIAO QING, PAN WANG, ZOU DONG-SHENG, et al. Using of g- $\mathrm{C}_{3} \mathrm{~N}_{4}$ nanosheets for the highly efficient scavenging of heavy metals at environmental relevant concentrations. Journal of Molecular Liquids, 2018, 261: 32-40.

[3] ZIMMERMAN J B, MIHELCIC J R, SMITH J. Global stressors on water quality and quantity. Environmental Science \& Technology, 2008, 42(12): 4247-4254.

[4] ZHAO GUI-XIA, WU XI-LIN, TAN XIAO-LI, et al. Sorption of heavy metal ions from aqueous solutions: a review. The Open Colloid Science Journal, 2011, 4: 19-31.

[5] ABBAS K, ZNAD H, AWUAL M R. A ligand anchored conjugate adsorbent for effective mercury(II) detection and removal from aqueous media. Chemical Engineering Journal, 2018(334): 432-443.

[6] ZHANG SHOU-WEI, WANG XIANG-XUE, LI JIA-XING, et al. Efficient removal of a typical dye and $\mathrm{Cr}(\mathrm{VI})$ reduction using $\mathrm{N}$-doped magnetic porous carbon. RSC Advances, 2014, 4(108): 63110-63117.

[7] WANG ZHANG-HONG, SHEN DE-KUI, SHEN FEI, et al. Equilibrium, kinetics and thermodynamics of cadmium ions $\left(\mathrm{Cd}^{2+}\right)$ removal from aqueous solution using earthworm manure-derived carbon materials. Journal of Molecular Liquids, 2017, 241: 612-621.

[8] NADERI A, DELAVAR M A, GHORBANI Y, et al. Modification of nano-clays with ionic liquids for the removal of Cd (II) ion from aqueous phase. Appied Clay Science, 2018, 158: 236-245.

[9] ZHOU GUANG-ZHU, WANG YUE, ZHOU RUN-SHENG, et al. Synthesis of amino-functionalized bentonite/ $\mathrm{CoFe}_{2} \mathrm{O}_{4} @ \mathrm{MnO}_{2}$ magnetic recoverable nanoparticles for aqueous $\mathrm{Cd}^{2+}$ removal. Science of the Total Environment, 2019, 682: 505-513.

[10] AWUAL M R, KHRAISHEH M, ALHARTHI N H, et al. Efficient detection and adsorption of cadmium(II) ions using innovative nano-composite materials. Chemical Engineering Journal, 2018, 343: $118-127$.

[11] GUPTA V K, ALI I, SALEH T A, et al. Chemical treatment technologies for waste-water recycling: an overview. RSC Advances, 2012, 2(16): 6380-6388.

[12] MATURANA H A, PERIC I M, RIVAS B L, et al. Interaction of heavy metal ions with an ion exchange resin obtained from a natural polyelectrolyte. Polymer Bulletin, 2011, 67 (4): 669-676.

[13] MUNGRAY A A, KULKARNI S V, MUNGRAY A K. Removal of heavy metals from wastewater using micellar enhanced ultrafiltration technique: a review. Central European Journal of Chemistry, 2012, 10(1): 27-46.

[14] KUMAR K S, DAHMS H U, WON E J, et al. Microalgae-a 
promising tool for heavy metal remediation. Ecotoxicology and Environmental Safety, 2015, 113: 329-352.

[15] QDAIS H A, MOUSSA H. Removal of heavy metals from wastewater by membrane processes: a comparative study. Desalination, 2004, 164: 105-110.

[16] INGLEZAKIS V J, LOIZIDOU M D. Ion exchange of some heavy metal ions from polar organic solvents into zeolite. Desalination, 2007, 211: 238-248.

[17] MATLOCK M M, HOWERTON B S, ATWOOD D A. Chemical precipitation of heavy metals from acid mine drainage. Water Research, 2002, 36: 4757-4764.

[18] GUPTA V K, SALEH T A. Sorption of pollutants by porous carbon, carbon nanotubes and fullerene-an overview. Environmental Science and Pollution Research, 2013, 20(5): 2828-2843.

[19] LIAO QING, YAN SHUN-RONG, LINGHU WEN-SHENG, et al. Impact of key geochemical parameters on the highly efficient sequestration of $\mathrm{Pb}$ (II) and $\mathrm{Cd}(\mathrm{II})$ in water using $\mathrm{g}-\mathrm{C}_{3} \mathrm{~N}_{4}$ nanosheets. Journal of Molecular Liquids, 2018, 258: 40-47.

[20] ZHANG HAI-FENG, DANG QI-FENG, LIU CHENG-SHENG, et al. Fabrication of methyl acrylate and tetraethylenepentamine grafted magnetic chitosan microparticles for capture of $\mathrm{Cd}(\mathrm{II})$ from aqueous solutions. Journal of Hazardous Materials, 2019, 366: 346-357.

[21] CIESIELCZYK F, BARTCZAK P, JESIONOWSKI T. A comprehensive study of $\mathrm{Cd}(\mathrm{II})$ ions removal utilizing high-surface-area binary Mg-Si hybrid oxide adsorbent. International Journal of Environmental Science and Technology, 2015, 12(11): 3613-3626.

[22] DIAZ-FLORES P E, LOPEZ-URIAS F, TERRONES M, et al. Simultaneous adsorption of $\mathrm{Cd}^{2+}$ and phenol on modified $\mathrm{N}$-doped carbon nanotubes: experimental and DFT studies. Journal of Colloid and Interface Science, 2009, 334 (2): 124-131.

[23] HUANG JIE-YING, WU ZHEN-WEI, CHEN LI-WEI, et al. Surface complexation modeling of adsorption of $\mathrm{Cd}(\mathrm{II})$ on graphene oxides. Journal of Molecular Liquids, 2015, 209: 753-758.

[24] SHENG GUO-DONG, ALSAEDI A, SHAMMAKH W, et al. Enhanced sequestration of selenite in water by nanoscale zero valent iron immobilization on carbon nanotubes by a combined batch, XPS and XAFS investigation. Carbon, 2016, 99: 123-130.

[25] BOPARAI H K, JOSEPH M, O'CARROLL D M, et al. Kinetics and thermodynamics of cadmium ion removal by adsorption onto nano zerovalent iron particles. Journal of Hazardous Materials, 2011, 186(1): 458-465.

[26] MOSTAFA M S, BAKR A A. Adsorptive removal of Cd(II) from contaminated water via hexavalent molybdenum-containing layered double hydroxide: Ni/Mo-LDH. Energy Sources Part A-Recovery Utilization and Environmental Effects, 2019, 41(18): 2257-2265.

[27] RAHMANIAN O, MALEKI M H, DINARI M. Ultrasonically assisted solvothermal synthesis of novel Ni/Al layered double hydroxide for capturing of $\mathrm{Cd}(\mathrm{II})$ from contaminated water. Journal of Physics and Chemistry of Solids, 2017, 110: 195-201.

[28] WENG QUN-HONG, WANG XUE-BIN, WANG XI, et al. Functionalized hexagonal boron nitride nanomaterials: emerging properties and applications. Chemical Society Reviews, 2016, 45(14):
3989-4012.

[29] YU SHU-JUN, WANG XIANG-XUE, PANG H W, et al. Boron nitride-based materials for the removal of pollutants from aqueous solutions: a review. Chemical Engineering Journal, 2018, 333: 343-360.

[30] LI JIE, LI JING, XU WUE-WEN, et al. Porous boron nitride with high surface area: hydrogen storge and water treatment. Nanotechnology, 2013, 24(15): 155603.

[31] XUE YAN-MING, DAI PENG-CHENG, JIANG XIANG-FEN, et al. Template-free synthesis of boron nitride foam-like porous monoliths and their high-end applications in water purification. Journal of Materials Chemistry A, 2016, 4(4): 1469-1478.

[32] LI JIE, JIN PENG, TANG CHENG-CHUN. Cr(III) adsorption by fluorinated activated boron nitride: a combined experimental and theoretical investigation. RSC Advances, 2014, 4(29): 14815-14821.

[33] SONG QIAN-QIAN, FANG YI, LIU ZHEN-YA, et al. The performance of porous hexagonal $\mathrm{BN}$ in high adsorption capacity towards antibiotics pollutants from aqueous solution. Chemical Engineering Journal, 2017, 325: 71-79.

[34] LI JIE, HUANG YANG, LIU ZHEN-YA, et al. Chemical activation of boron nitride fibers for improved cationic dye removal performance. Journal of Materials Chemistry, 2015, 3(15): 8185-8193.

[35] CHEN MING-MING, WEI DA, CHU WEI, et al. One-pot synthesis of O-doped BN nanosheets as capacitive deionization electrode for efficient removal of heavy metal ions from water. Journal of Materials Chemistry A, 2017, 5(32): 17029-17039.

[36] LI JIE, XIAO XING, XU XUE-WEN, et al. Activated boron nitride as an effective adsorbent for metal ions and organic pollutants. Scientific Reports, 2013, 3: 3208.

[37] TANG CHENG-CHUN, BANDO Y, HUANG Y, et al. Synthetic routes and formation mechanisms of spherical boron nitride nanoparticles. Advanced Functional Materials, 2008, 18(22): 3653-3661.

[38] ZHI CHUN-YI, BANDO Y, TANG CHENG-CHUN, et al. Phonon characteristics and cathodelumininescence of boron nitride nanotubes. Applied Physics Letters, 2015, 86(21): 213110.

[39] GEORGE S. Infrared and Raman Characteristic Group Frequencies: Tables and Charts, $3^{\text {rd }}$ Edition. New York: Wiley, 2001: 107-113.

[40] HO YUH-SHAN, MCKAY GORDON. Pseudo-second order model for sorption processes. Process Biochemistry, 1999, 34(5): 451-465.

[41] ZHANG LEI, SONG XIAO-YAN, LIU XUE-YAN, et al. Studies on the removal of tetracycline by multi-walled carbon nanotubes. Chemical Engineering Journal, 2011, 178: 26-33.

[42] LI PING, YIN ZHOU-XIN, LIN JIAN-FENG, et al. The immobilization of $\mathrm{U}(\mathrm{VI})$ on iron oxyhydroxides under various physicochemical conditions. Environmental Science-Processes\& Impacts, 2014, 16(10): 2278-2287.

[43] Handbook of the Elements and Native Oxides, XPS International, Inc. 1999

[44] PENG DONG, JINAG WEI, LI FANG-FANG, et al. One-pot synthesis of boron carbon nitride nanosheets for facile and efficient heavy metal ions removal. ACS Sustainable Chemistry\&Engineering, 2018, 6(9): 11685-11694. 


\title{
氮化硼纳米片吸附 $\mathrm{Cd}(\mathrm{II})$ 的动力学和热力学研究
}

\author{
李 网 $^{1}$ ，郭筱洁 ${ }^{2}$ ，金 阳 ${ }^{1}$ ，陈朝贵 ${ }^{1}$, Abdullah M Asiri $^{3}$ ， \\ Hadi M Marwani ${ }^{3}$ ，赵轻舟 ${ }^{4}$ ，盛国栋
}

(1. 绍兴文理学院 化学与化工学院, 绍兴 $312000 ; 2$. 杭州电子大学 材料与环境工程学院, 杭州 310018 ; 3. Chemistry Department, Faculty of Science, King Abdulaziz University, Jeddah 21589, Saudi Arabia; 4. 中国科学院大 学 资源与环境学院, 北京 100049)

摘 要: 本工作对 $\mathrm{Cd}(\mathrm{II})$ 在多孔六方氮化嗍 $(\mathrm{p}-\mathrm{BN})$ 上的吸附行为和机理进行了系统而全面的研究, 考察了溶液 $\mathrm{pH}$ 、 吸附剂用量、接触时间和温度等条件对于 $\mathrm{Cd}(\mathrm{II})$ 吸附的影响, 并采用不同手段表征了吸附前后 $\mathrm{p}-\mathrm{BN}$ 的化学组成、 形态和表面官能团的变化, 进而研究其吸附机理。研究结果显示, 在 $\mathrm{pH} 7.0$ 和 $313 \mathrm{~K}$ 条件下, $\mathrm{Cd}(\mathrm{II})$ 的最大吸附容量 可达到 $184 \mathrm{mg} \cdot \mathrm{g}^{-1}$, 其动力学数据与拟二级模型和颗粒内扩散模型吻合, 表明吸附主要受化学吸附控制, 限速步骤 主要是分子扩散。 $\mathrm{Cd}(\mathrm{II})$ 在 p-BN 上的吸附是一个自发和吸热过程, 吸附等温线分别符合 Freundlich 和 Langmuir 模 型, 说明 $\mathrm{Cd}(\mathrm{II})$ 通过多层和单层吸附而吸附在非均相表面上。XPS 的光谱结果显示, p-BN 吸附剂具有大量的 B-N, B-O 等结构用作键合位点, 有利于从废水中吸收 Cd(II)。这些结果表明, p-BN 有希望作为吸附材料用于清除水体中 的 $\mathrm{Cd}(\mathrm{II})$ 。

关 键 词: 氮化硼; 吸附; Cd(II); 重金属

中图分类号: TQ174 文献标识码: A 


\title{
Suppporting Materials
}

\section{Distinguished Cd(II) Capture with Rapid and Superior Ability using Porous Hexagonal Boron Nitride: Kinetic and Thermodynamic Aspects}

\author{
$\mathrm{LI} \mathrm{Li}^{1}$, GUO Xiaojie ${ }^{2}$, JIN Yang ${ }^{1}$, CHEN Chaogui ${ }^{1}$, Abdullah M Asiri ${ }^{3}$, \\ Hadi M Marwani ${ }^{3}$, ZHAO Qingzhou ${ }^{4}$, SHENG Guodong ${ }^{1}$
}

(1. College of Chemistry and Chemical Engineering, Shaoxing University, Shaoxing 312000, China; 2. College of Materials \& Environmental Engineering, Hangzhou Dianzi University, Hangzhou 310018, China; 3. Chemistry Department, Faculty of Science, King Abdulaziz University, Jeddah 21589, Saudi Arabia; 4. College of Resources and Environment, University of Chinese Academy of Sciences, Beijing 100049, China)

\section{BET characterization}

Fig. S2 illustrates $\mathrm{N}_{2}$ adsorption-desorption isotherm $(77 \mathrm{~K})$ and the corresponding pore size distribution of p-BN. The measured isotherm (Fig. S2(a)) can be classified as a type I isotherm and an $\mathrm{H} 4$ type broad hysteresis loop between the relative pressure $\left(p / p_{0}\right)$ of 0.47 and 0.99 . This indicates $\mathrm{p}-\mathrm{BN}$ material is filled with micro porosity and narrow slit-shaped mesopores, which would increase the contact probability and be favorable for adsorption ${ }^{[1]}$. Meanwhile, the corresponding Barrett-Joyner-Halenda (BJH) pore-size distribution curve of $\mathrm{p}$-BN micro rods are illustrated in Fig. S2(b), the calculated pore volume is $0.070 \mathrm{~cm}^{3} \cdot \mathrm{g}^{-1}$ and the major characteristic pore size is $\sim 2.62 \mathrm{~nm}$. Besides, the BET specific surface area is $66.0 \mathrm{~m}^{2} \cdot \mathrm{g}^{-1}$, which can provide more activated site and be beneficial for adsorption.

\section{Fitting results by four kinetic models}

Fig. S4(A-D) illustrate the fitting results by 4 kinetic models, the corresponding kinetic parameters are listed in Table S1. The results (Fig. S4(A-B)) obtained from the analysis of experimental data reveals that adsorption of $\mathrm{Cd}(\mathrm{II})$ on $\mathrm{p}-\mathrm{BN}$ is best described by pseudo-second-order

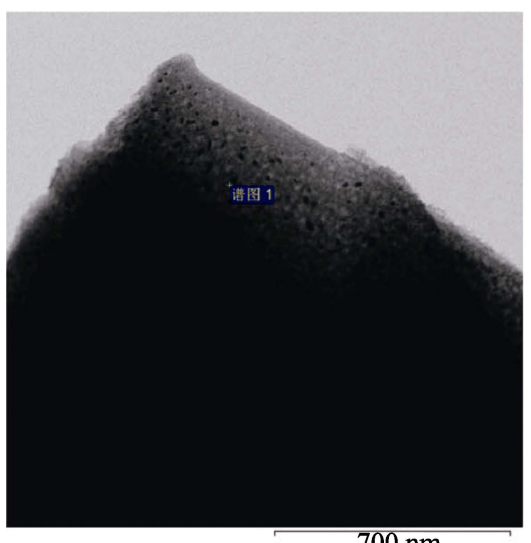

$700 \mathrm{~nm}$

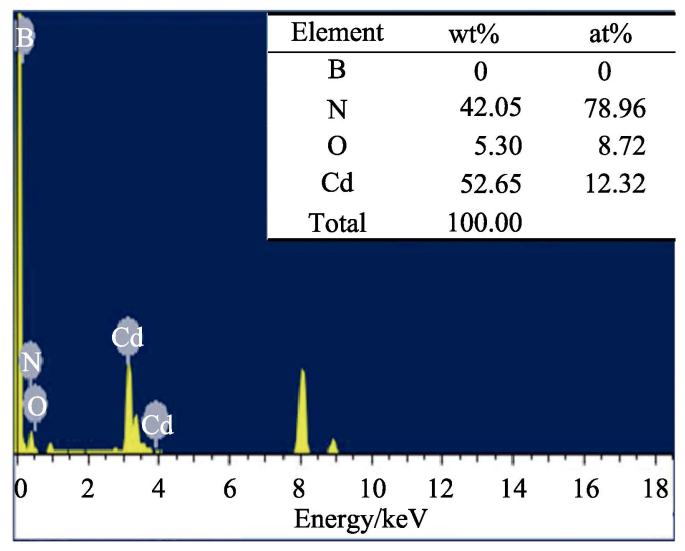

Fig. S1 Energy spectrum analysis (ESA) for unidentified black dots adsorbed on p-BN
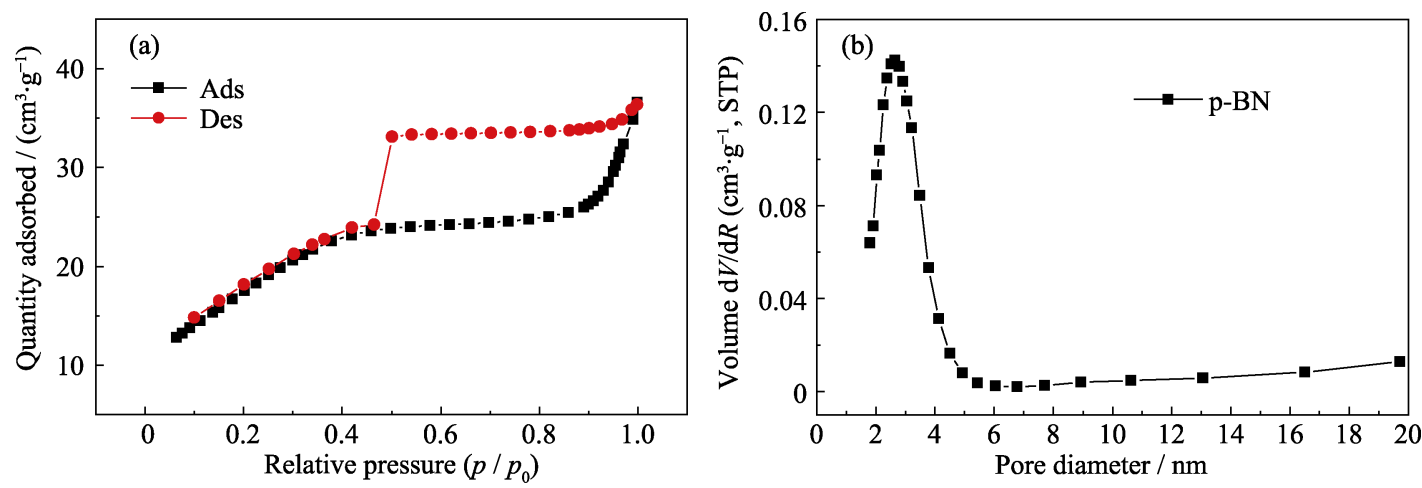

Fig. S2 BET measurement of p-BN

(a) $\mathrm{N}_{2}$ adsorption-desorption isotherm; (b) BJH pore-size distribution curve 


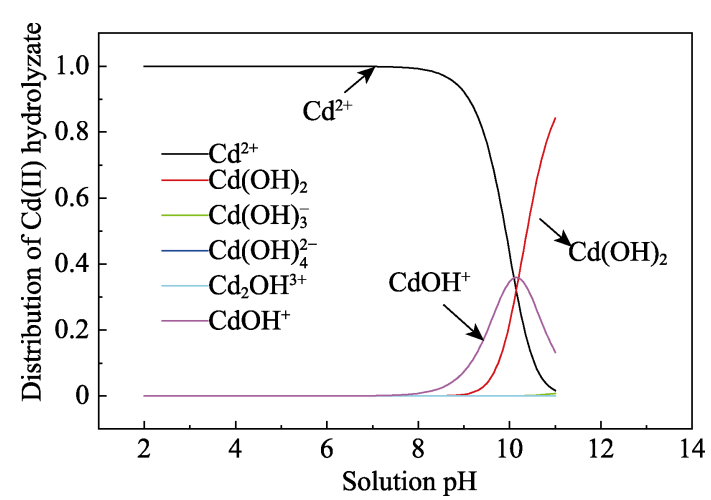

Fig. S3 Variation of distribution of Cd(II) hydrolyzate species with $\mathrm{pH}$

model. The linear fitting coefficient is as high as 0.999 and the theoretically calculated adsorption capacity $\left(q_{\mathrm{e}, \mathrm{cal}}=193.1 \mathrm{mg} \cdot \mathrm{g}^{-1}\right)$ is very close to the experimental result $\left(q_{\mathrm{e}}=184.0 \mathrm{mg} \cdot \mathrm{g}^{-1}\right)$. These indicate that the adsorption process involves the sharing or transfer of electrons between the adsorbent and the adsorbate ${ }^{[2]}$, and the adsorption process is mainly controlled by chemisorption. Additionally, two distinct regions (Fig. S4(C)) are observed in the intra-particle diffusion diagram, the piecewise linear regressions suggest that the adsorption process can be divided into two stages, external mass transfer and intra-particle diffusion ${ }^{[3]}$. The rapid adsorption of the first stage is attributed to the larger surface area and more activated adsorption sites. The second stage of adsorption relies on the molecular diffusion of $\mathrm{Cd}(\mathrm{II})$ in $\mathrm{p}-\mathrm{BN}$ micropores, which is slow and has a limited rate of adsorption. The liquid membrane diffusion model has a relatively low linear fitting coefficient value ( $R^{2}=0.948$ ) for fitting the experimental data (Fig. S4(D)), demonstrating that the rate limiting step is primarily molecular diffusion of $\mathrm{Cd}(\mathrm{II})$ in the micropores of $\mathrm{p}-\mathrm{BN}^{[1]}$.

\section{Adsorption thermodynamic}

The thermodynamic parameters of the adsorption, i.e. the values of standard Gibbs free energy $\left(\Delta G^{\theta}\right)$, enthalpy ( $\Delta H^{\theta}$ ) and entropy $\left(\Delta S^{\theta}\right)$ are calculated by the following formulas (11-13):

$$
\begin{gathered}
K_{\mathrm{d}}=\frac{C_{0}-C_{\mathrm{e}}}{C_{\mathrm{e}}} \times \frac{V}{m} \\
\ln K_{\mathrm{d}}=-\frac{\Delta H^{\theta}}{R} \times \frac{1}{T}+\frac{\Delta S^{\theta}}{R} \\
\Delta G^{\theta}=\Delta H^{\theta}-T \times \Delta S^{\theta}
\end{gathered}
$$

Where $K_{\mathrm{d}}$ is the distribution coefficient and $R$ is the molar gas constant $\left(8.314 \mathrm{~J} \cdot \mathrm{mol}^{-1} \mathrm{~K}^{-1}\right)$. Briefly, $K_{\mathrm{d}}$ is linear with $1 / T$ and presented in Fig. S5. The slope and intercept of the fitted curve can be used to calculate $\Delta H^{\theta}$ and $\Delta S^{\theta}$, and then calculate $\Delta G^{\theta}$. The thermodynamic parameters are summarized in Table S2. The negative
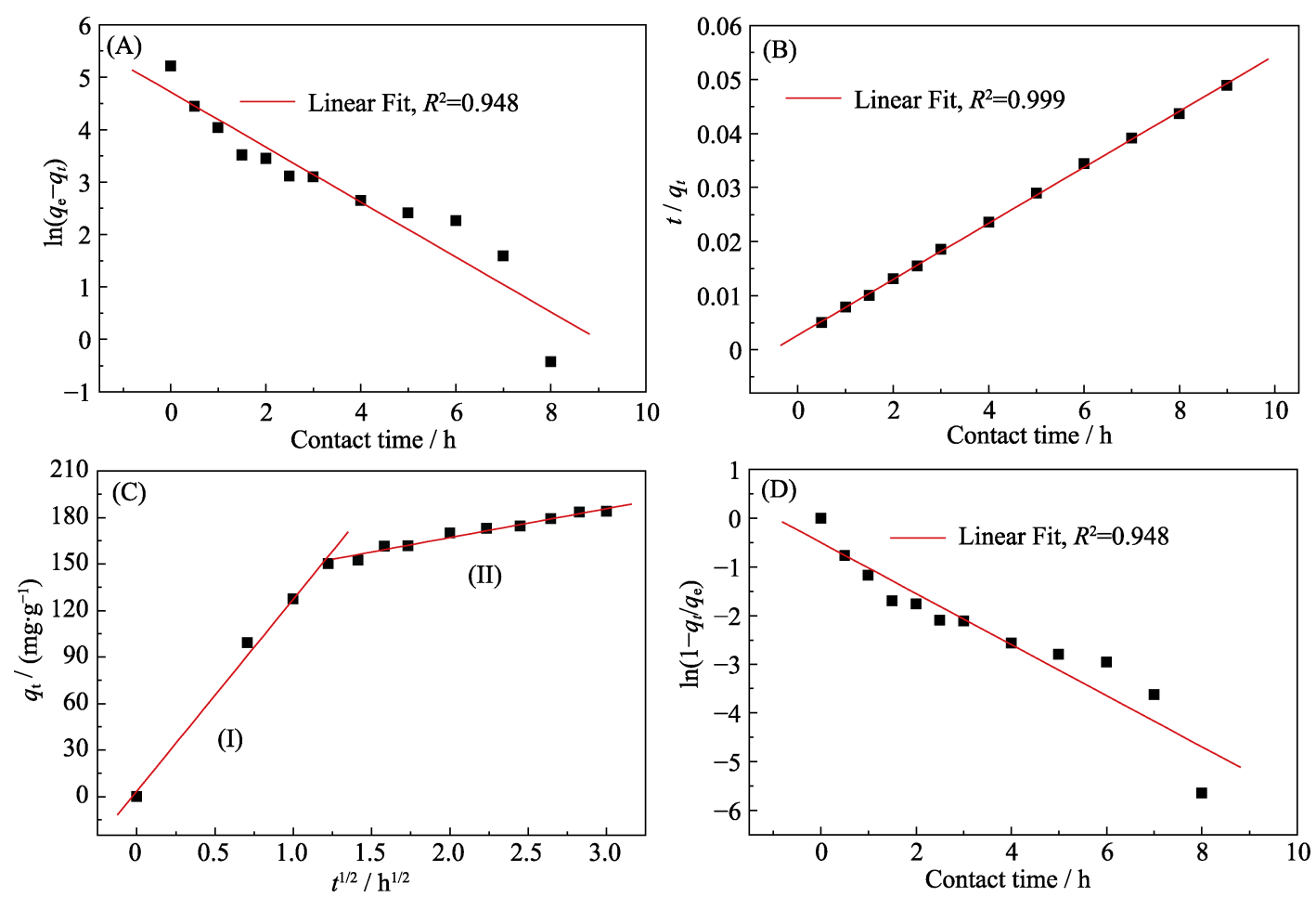

Fig. S4 Kinetics models for adsorption of Cd(II) on p-BN

(A) Pseudo-first-order model; (B) Pseudo-second-order model; (C) Intra-particle diffusion model; (D) Liquid-film diffusion model. Experimental conditions: Initial $\mathrm{pH}$ at $7.0, C_{0}=60 \mathrm{mg} \cdot \mathrm{L}^{-1}, m=10.0 \mathrm{mg}, V=50 \mathrm{~mL}$ 
values of $\Delta G^{\theta}$ and the positive values of $\Delta H^{\theta}$ confirm that the adsorption of $\mathrm{Cd}(\mathrm{II})$ on $\mathrm{p}$-BN is a endothermic and spontaneous process. The increase of temperature made $\Delta G^{\theta}$ more negative, indicating that high temperature is beneficial to the adsorption, which is consistent with the results of adsorption capacities at different temperatures.

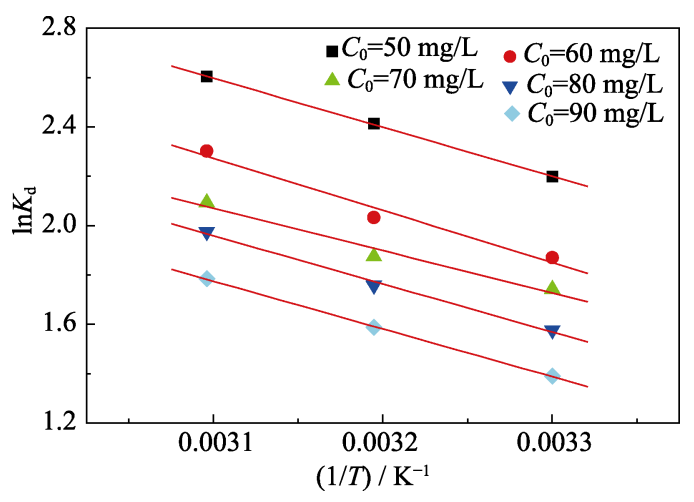

Fig. S5 Linear plots of $\ln K_{\mathrm{d}}$ versus $1 / T$ for $\mathrm{Cd}(\mathrm{II})$ adsorption on $\mathrm{p}-\mathrm{BN}$ adsorbent
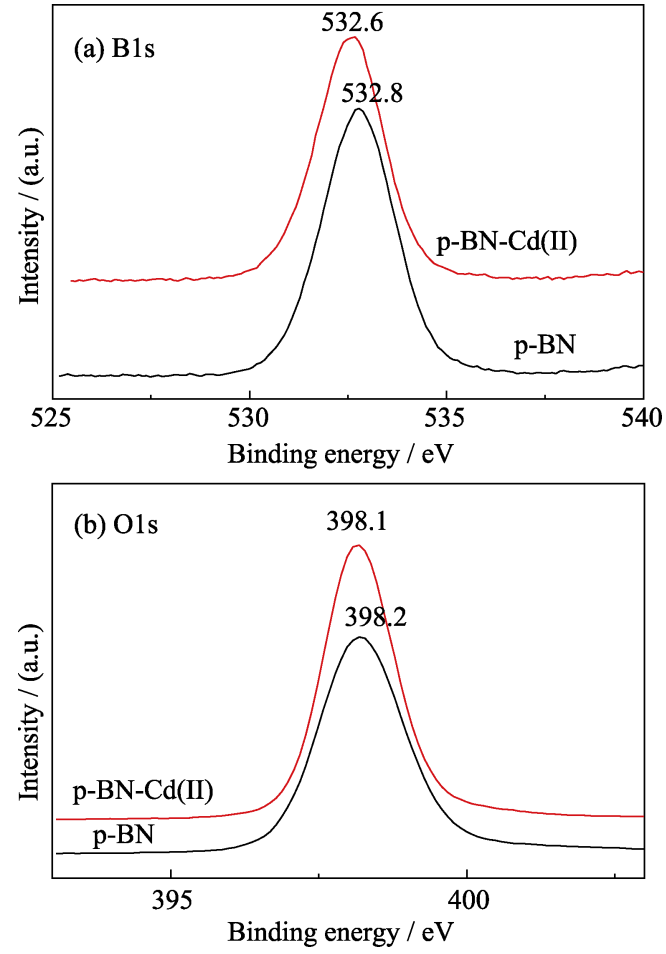

Fig. S6 High resolution spectra of B1s (a) and O1s (b) for p-BN before and after adsorption

Table S1 Adsorption kinetics models parameters

\begin{tabular}{|c|c|c|c|c|c|c|c|c|}
\hline \multirow{3}{*}{$\mathrm{Cd}(\mathrm{II}) / \mathrm{p}-\mathrm{BN}$} & \multicolumn{8}{|c|}{ Model } \\
\hline & \multicolumn{2}{|c|}{ Pseudo-first-order } & \multicolumn{2}{|c|}{ Pseudo-second-order } & \multicolumn{2}{|c|}{ Intra-particle diffusion } & \multicolumn{2}{|c|}{ Liquid-film diffusion } \\
\hline & $q_{\mathrm{e}, \mathrm{cal}} /\left(\mathrm{mg} \cdot \mathrm{g}^{-1}\right)$ & 111.7 & $q_{\mathrm{e}, \mathrm{cal}} /\left(\mathrm{mg} \cdot \mathrm{g}^{-1}\right)$ & 193.1 & $I$ & 60.2 & $K_{\mathrm{f}} / \mathrm{h}^{-1}$ & 0.524 \\
\hline \multirow[t]{2}{*}{ Parameters } & $k_{1}^{-1}$ & 0.524 & $k_{2}\left(\mathrm{~g} \cdot \mathrm{mg}^{-1} \cdot \mathrm{h}^{-1}\right)$ & $1.00 \times 10^{-3}$ & $k_{\mathrm{d}} /\left(\mathrm{g} \cdot \mathrm{mg}^{-1} \cdot \mathrm{h}^{-1 / 2}\right)$ & 49.4 & $A$ & -0.499 \\
\hline & $R^{2}$ & 0.948 & $R^{2}$ & 0.999 & $R^{2}$ & 0.872 & $R^{2}$ & 0.948 \\
\hline
\end{tabular}

Table S2 Values of thermodynamic parameters for the adsorption of Cd(II) on p-BN

\begin{tabular}{ccccccc}
\hline \multirow{2}{*}{ Adsorbate } & \multirow{2}{*}{$C_{0} /\left(\mathrm{mg} \cdot \mathrm{L}^{-1}\right)$} & $\Delta H^{\theta} /\left(\mathrm{kJ} \cdot \mathrm{mol}^{-1}\right)$ & $\Delta S^{\theta} /\left(\mathrm{J} \cdot \mathrm{mol}^{-1} \cdot \mathrm{K}^{-1}\right)$ & \multicolumn{4}{c}{$\Delta G^{\theta} /\left(\mathrm{kJ} \cdot \mathrm{mol}^{-1}\right)$} \\
\cline { 5 - 7 } & 50 & 16.51 & 72.81 & $303 \mathrm{~K}$ & $313 \mathrm{~K}$ & $323 \mathrm{~K}$ \\
\hline \multirow{3}{*}{ Cd(II) } & 60 & 17.58 & 73.40 & -5.55 & -6.28 & -7.01 \\
& 70 & 14.25 & 61.39 & -4.35 & -4.97 & -6.13 \\
& 80 & 16.21 & 66.54 & -3.95 & -4.62 & -5.28 \\
\hline
\end{tabular}

\section{References:}

[1] SONG QIAN-QIAN, FANG YI, LIU ZHEN-YA, et al. The performance of porous hexagonal $\mathrm{BN}$ in high adsorption capacity towards antibiotics pollutants from aqueous solution. Chemical
Engineering Journal, 2017, 325: 71-79.

[2] HO YUH-SHAN, MCKAY GORDON, Pseudo-second order model for sorption processes. Process Biochemistry, 1999, 34(5): 451-465.

[3] ZHANG LEI, SONG XIAO-YAN, LIU XUE-YAN, et al. Studies on the removal of tetracycline by multi-walled carbon nanotubes. Chemical Engineering Journal, 2011, 178: 26-33. 